\title{
THE EFFECT OF USE OF DIFFERENT DOSES OF URSODEOXYCOLIC ACID ON GALLSTONE FORMATION AFTER SLEEVE GASTRECTOMY
}

\author{
SLEEVE GASTREKTOMI SONRASI FARKLI DOZLARDA URSODEOKSIKOLIK ASIT \\ KULLANIMININ SAFRA TAŞI OLUŞUMUNA ETKISI
}

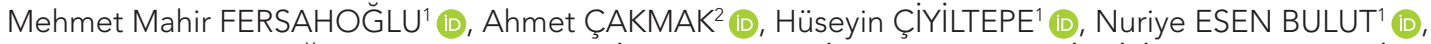

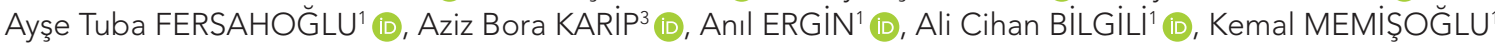 \\ ${ }^{1}$ Health Sciences University, Istanbul Fatih Sultan Mehmet Training and Research Hospital, General Surgery Clinic, Istanbul, Turkey \\ ${ }^{2}$ Sinop Ayancik State Hospital, Sinop, Turkey \\ ${ }^{3}$ Istanbul Oncology Hospital, Department of General Surgery, Istanbul, Turkey
}

ORCID IDs of the authors: M.M.F. 0000-0003-2526-1832; A.C. 0000-0001-8768-2267; H.C. 0000-0003-3048-1784;

N.E.B. 0000-0002-4845-8964; A.T.F. 0000-0002-3083-2276; A.B.K. 0000-0001-8768-2267; A.E. 0000-0001-6450-7124;

A.C.B. 0000-0001-5009-6328; K.M. 0000-0002-9486-4648

Cite this article as: Fersahoglu MM, Cakmak A, Ciyiltepe H, Esen Bulut N, Fersahoglu AT, Karip AB, et al. The effect of use of different doses of ursodeoxycolic acid on gallstone formation after sleeve gastrectomy. J Ist Faculty Med 2022;85(1):29-34.

doi: 10.26650/IUITFD.948141

\section{ABSTRACT}

Objective: To evaluate the effects of using different doses of ursodeoxycholic acid (UDCA) for six months in prevention of gallstones after Laparoscopic Sleeve Gastrectomy (LSG) on the formation of gallstones in the $6^{\text {th }}$ and $12^{\text {th }}$ months.

Materials and Methods: The data of patients who underwent LSG for morbid obesity were analyzed. Three groups of 20 people were formed. These were the control group, Group I who were treated with UCDA $500 \mathrm{mg} /$ day for six months after LSG, and Group II who were treated with UCDA 1000 mg/day for 6 months after LSG. Demographic characteristics, co-morbid diseases, cholesterol and triglyceride differences before and after surgery, excess weight loss (EWL\%), total weight loss (TWL\%), body mass index (BMI), and abdominal ultrasound (US) data for the occurrence of cholelithiasis (CL) preoperatively and at six and 12 months after surgery were collected.

Results: The results of tests taken on these patients in the sixth month revealed that the stone detection rate in the US results of the control group was significantly higher than that in Group II $(p=0.001 ; p<0.01)$. There was no statistically significant difference between the control group and Group I $(p=0.149)$, and between Group I and Group II ( $p=0.066)$. The results of tests taken in the $12^{\text {th }}$ month showed that the stone detection rate in the US results of the control group was significantly higher than Group I and Group II ( $p=0.010 ; p<0.05)$. There was no statistically significant difference between Group I and Group II.

\section{ÖZET}

Amaç: Laparoskopik Sleeve Gastrektomi (LSG) sonrası safra taşlarının önlenmesinde altı ay boyunca farklı dozlarda ursodeoxycholic acid (UDCA) kullanımının 6. ve 12. aylarda safra taşı oluşumuna etkilerini değerlendirmek.

Gereç ve Yöntem: Morbid obezite nedeniyle LSG uygulanan hastaların verileri analiz edildi. 20'şer kişilik üç grup oluşturuldu: Kontrol grubu; LSG sonrası altı ay süreyle UCDA 500 mg/gün ile tedavi edilen Grup I; LSG sonrası altı ay süreyle UCDA 1000 mg/ gün ile tedavi edilen Grup II. Demografik özellikler, eşlik eden hastalıklar, ameliyat öncesi ve sonrası kolesterol ve trigliserit farklılıkları, aşırı kilo kaybı (\%EWL), toplam kilo kaybı (\%TWL), vücut kitle indeksi (BMI) ve abdominal ultrason (US) verileri ameliyat öncesi ve ameliyattan altı ve 12 ay sonra kolelitiazis (CL) gelişimi değerlendirildi.

Bulgular: Olguların 6. ay sonuçlarında kontrol grubunun US sonuçlarında taş tespit oranı Grup II'ye göre anlamlı olarak yüksek bulundu ( $p=0,001 ; p<0,01)$. Kontrol grubu ile Grup I arasında $(p=0,149)$, Grup I ile Grup II arasında $(p=0,066)$ istatistiksel olarak anlamlı fark yoktu. Olguların 12. ay sonuçlarında kontrol grubunun US sonuçlarında taş tespit oranı Grup I ve Grup II'ye göre anlamlı olarak yüksek bulundu $(p=0,010 ; p<0,05)$. Grup I ve Grup II arasında istatistiksel olarak anlamlı fark yoktu.

Sonuç: Bu çalışma sonucunda hastalara LSG sonrası 1000 mg/ gün UDCA verilmesini öneriyoruz.

Corresponding author/iletişim kurulacak yazar: fersahoglu@yahoo.com

Submitted/Başvuru: 08.06.2021 • Accepted/Kabul: 10.11.2021 • Published Online/Online Yayın: 19.01.2022 
Conclusion: As a result of this study, we recommend that patients be given $1000 \mathrm{mg} /$ day UDCA after LSG.

Keywords: Cholelithiasis, laparoscopic sleeve gastrectomy, ursodeoxycholic acid
Anahtar Kelimeler: Kolelitiazis, laparoskopik sleeve gastrektomi, ursodeoksikolik asit

\section{INTRODUCTION}

While cholelithiasis (CL) incidence is around $5 \%$ in the general population, this incidence can rise to $45 \%$ in the obese population, especially in female patients (1-3). It is known today that bariatric surgical methods cause gallstones in patients. Additionally, bariatric methods can cause a-symptomatic gallstones to become symptomatic (such as biliary colic, cholecystitis, cholangitis, or pancreatitis) (4).

Obesity can be defined as the excessive accumulation of fat in the body. Body fat is between $15-20 \%$ in males with an average body weight and $25-30 \%$ in females. Since it is not easy to determine body fat percentage, obesity is defined as being overweight rather than being excessively fat. According to the World Health Organization (WHO) obesity is classified by calculating the body mass index (BMl=Weight $[\mathrm{kg}] /$ Height $\left.\left[\mathrm{m}^{2}\right]\right)$. Accordingly, BMI=25.0$29.9 \mathrm{~kg} / \mathrm{m}^{2}$ is classified as overweight, and $B M l \geq 30 \mathrm{~kg} / \mathrm{m}^{2}$ is classified as obesity (5). $30-34.9 \mathrm{~kg} / \mathrm{m}^{2}$ is defined as Grade 1 obesity, $35-39.9 \mathrm{~kg} / \mathrm{m}^{2}$ is defined as Grade 2 obesity, and $\geq 40 \mathrm{~kg} / \mathrm{m}^{2}$ is defined as Grade 3, or morbid obesity (5).

It has been reported that gallstones can increase due to metabolic disorders such as diabetes mellitus (DM) and to excess estrogen, which can increase the cholesterol content of bile (6). In studies conducted on this topic, the difference between the presence of chronic diseases and the formation of gallstones was found to be statistically significant $(7,8)$.

Changes in cholesterol metabolism involving rapid weight loss increase the cholesterol concentration in bile. Undissolved cholesterol crystallizes in company with a glycoprotein that stimulates cholesterol crystal aggregation. This particularly occurs with calcium $\left(\mathrm{Ca}^{+2}\right)$ and mucin (9) which increase 10-20 times in bile after bariatric surgery with an unknown mechanism $(9,10)$. Various rates of gallstone formation incidence have been reported after different bariatric procedures. Although the incidence of symptomatic gallstones was reported to be higher in LSG compared to Roux-en-Y Gastric Bypass (RYGB) in only one of the studies conducted to date, no significant difference was found between them (11). Gallstone development has been reported at a rate of $10-25 \%$ after a calorie-restricted diet $(12,13)$. Morbidly obese patients were observed to develop gallstones at a rate of $35-38 \%$ when they lost weight after bariatric surgery $(9,14,15)$.

With ursodeoxycholic acid (UDCA), it is possible to medically prevent $C L$, which occurs as a result of rapid weight loss. In the prevention of gallstones, UDCA is a secondary bile acid that acts by increasing the flow rate of bile and decreasing its lithogenicity. Use of UDCA for three to six months was found to effectively prevent CL formation up to 24 months after surgery (Odds Ratio (OR) 0.43) (16). In all studies conducted to date, though the relationship between UDCA use and gallbladder stone formation has been sought, the relationship of the latter with the dose of UDCA has not been investigated $(17,18)$.

In this study, we aimed to evaluate the effects of using different doses of UDCA for six months in the prevention of gallstones after LSG. We checked degrees of gallstone formation after 6 and 12 months.

\section{MATERIALS AND METHODS}

This study was planned as a prospective, randomized, controlled study. Patients who underwent LSG due to morbid obesity at the General Surgery Clinic in Fatih Sultan Mehmet Training and Research Hospital between July 2018 and July 2019 were evaluated. Approval from the hospital ethics committee was obtained, as was informed consent from all patients. (FSMEAH-KAEH 17073117-050.06). The patients were randomly grouped into 3 groups of 20 each using the website www.randomizer.org. Those who did not receive UDCA treatment after LSG were defined as the control group, those who received UCDA 500 mg/day for 6 months after LSG were defined as Group I, and those who received UCDA $1000 \mathrm{mg} /$ day for 6 months after LSG were defined as Group II. Before LSG, US was performed in all patients to detect the presence of stones in the gallbladder. The demographic characteristics of the patients, $\mathrm{DM}, \mathrm{HT}$, pre and postoperative cholesterol and triglyceride differences, EWL\%, TWL\%, and BMI values were analyzed. In addition, abdominal US reports were collected to evaluate CL formation before surgery and at 6 and 12 months after surgery.

\section{Inclusion criteria}

All patients above 18 years of age who had had LSG for the first time due to obesity and who had not had gallbladder surgery before were included in the study.

\section{Exclusion criteria}

- Detection of gallstones in US before LSG

- History of previous bariatric surgery or gall bladder surgery

- Presence of hypersensitivity to active or auxiliary components of UDCA 
- Inflammatory Bowel Disease (IBD) and pathologies involving the small intestines and liver that affect the enterohepatic circulation of bile salts (ileal resection and stoma, extra/intrahepatic cholestasis, severe liver disease)

- Pregnancy or use of contraception

- Failure to obtain informed consent

\section{RESULTS}

A total of 60 patients, $73.3 \%(n=44)$ of whom were female and $26.7 \%(n=16)$ of whom were male, were included in the study. The ages of the patients included in the study ranged from 19 to 61 , and the mean age was $36.58 \pm 10.82$. The median BMI was 43.8.

A comparison of demographic data such as age, gender, $\mathrm{BMI}$ and presence of DM revealed that no difference was found between the groups. However, the rate of hypertensive patients was coincidentally higher in Group I ( $\mathrm{Ta}$ ble 1).
No significant difference was found between these three groups in terms of EWL\%, TWL\%, cholesterol and triglyceride differences (Table 2).

A statistically significant difference was found between the postoperative 6th month US results of the cases according to UDCA use $(p=0.001 ; p<0.01)$. In the control group, the rate of $C L$ on US was found to be significantly higher than in Group II ( $p=0.001 ; p<0.01)$. In regards to stone formation, there was no significant difference between the control group and Group I $(p=0.149)$ and Group I and Group II ( $p=0.149)(p=0.066)$.

The difference between the distribution of postoperative 1 st year US results according to UDCA use was statistically significant ( $p=0.010 ; p<0.05)$. The incidence of $C L$ was found to be significantly higher in those who did not use UDCA (Table 3).

\section{Statistical analyses}

The NCSS (NumberCruncher Statistical System) 2007 (Kaysville, Utah, USA) program was used for statistical analysis. Descriptive statistical methods (mean, standard

Table 1: Evaluation of ursodeoxycholic acid intake according to descriptive characteristics

\begin{tabular}{|c|c|c|c|c|c|c|}
\hline & & \multicolumn{4}{|c|}{ UDCA intake status } & \multirow{2}{*}{$\begin{array}{c}\text { Test value } \\
\mathrm{p}\end{array}$} \\
\hline & & Total & $\begin{array}{l}\text { Control group } \\
\qquad(n=20)\end{array}$ & $\begin{array}{l}\text { Group I } \\
(n=20)\end{array}$ & $\begin{array}{l}\text { Group II } \\
(n=20)\end{array}$ & \\
\hline \multirow[t]{2}{*}{ Age } & Min-Max (Median) & $19-61(34)$ & 23-52 (31.5) & $24-61(36.5)$ & $19-57(31)$ & $F=0.839$ \\
\hline & Mean \pm SD & $36.58 \pm 10.82$ & $35.30 \pm 9.58$ & $39.15 \pm 11.32$ & $35.30 \pm 11.54$ & ${ }^{\mathrm{a}} 0.437$ \\
\hline \multirow[t]{2}{*}{ Gender } & Female, n (\%) & 44 (73.3) & $14(70.0)$ & $14(70.0)$ & $16(80.0)$ & $\chi^{2}=0.682$ \\
\hline & Male, n (\%) & $16(26.7)$ & $6(30.0)$ & $6(30.0)$ & $4(20.0)$ & ${ }^{\mathrm{b}} 0.711$ \\
\hline \multirow[t]{2}{*}{ Diabetes } & No, n (\%) & $48(80.0)$ & $17(85.0)$ & $16(80.0)$ & $15(75.0)$ & $\chi^{2}=0.684$ \\
\hline & Yes, n (\%) & $12(20.0)$ & $3(15.0)$ & $4(20.0)$ & $5(25.0)$ & 0.917 \\
\hline \multirow[t]{2}{*}{ Hypertension } & No, n (\%) & 49 (81.7) & $20(100.0)$ & $13(65.0)$ & $16(80.0)$ & $\chi^{2}=8.624$ \\
\hline & Yes, n (\%) & $11(18.3)$ & $0(0.0)$ & $7(35.0)$ & $4(20.0)$ & $0.011^{\star}$ \\
\hline BMI & & 43.8 & 43.2 & 45.6 & 42.4 & b0.154 \\
\hline
\end{tabular}

a: Oneway ANOVA, b: Pearson Chi-Square Test, c: Fisher-Freeman-Halton Test, *: $p<0.05$

Table 2: Evaluation of EWL, TWL, cholesterol, and triglyceride differences according to the status of ursodeoxycholic acid intake

\begin{tabular}{|c|c|c|c|c|c|c|}
\hline & & \multicolumn{4}{|c|}{ UDCA intake status } & \multirow{2}{*}{$\begin{array}{c}\text { Test value } \\
\mathrm{p}\end{array}$} \\
\hline & & Total & $\begin{array}{l}\text { Control group } \\
(n=20)\end{array}$ & $\begin{array}{c}\text { Group I } \\
(n=20)\end{array}$ & $\begin{array}{c}\text { Group II } \\
(n=20)\end{array}$ & \\
\hline EWL\% & Mean \pm SD & $59.22 \pm 13.21$ & $60.45 \pm 13.89$ & $59.20 \pm 14.23$ & $58.00 \pm 11.95$ & $\mathrm{a} 0.846$ \\
\hline TWL\% & Mean \pm SD & $30.08 \pm 5.83$ & $30.25 \pm 6.77$ & $29.85 \pm 5.44$ & $30.15 \pm 5.48$ & $\mathrm{a} 0.976$ \\
\hline Cholesterol difference & Mean \pm SD & $-1.36 \pm 30.99$ & $3.73 \pm 29.81$ & $-9.45 \pm 32.14$ & $1.65 \pm 30.89$ & $\mathrm{a} 0.357$ \\
\hline Triglyceride difference & Mean \pm SD & $-48.27 \pm 67.99$ & $-55.40 \pm 72.40$ & $-47.10 \pm 52.49$ & $-42.30 \pm 79.18$ & bo.555 \\
\hline
\end{tabular}

a: One-way ANOVA, b: Kruskal Wallis Test 
Table 3: Evaluation of ultrasound results according to the status of ursodeoxycholic acid intake

\begin{tabular}{|c|c|c|c|c|c|c|}
\hline \multirow{4}{*}{$\begin{array}{l}\text { Postoperative } 6^{\text {th }} \\
\text { month US result }\end{array}$} & & \multicolumn{4}{|c|}{ UDCA intake status } & \multirow{2}{*}{$\begin{array}{c}\text { Test value } \\
\text { p }\end{array}$} \\
\hline & & Total & $\begin{array}{c}\text { Control group } \\
(n=20)\end{array}$ & $\begin{array}{l}\text { Group I } \\
(n=20)\end{array}$ & $\begin{array}{c}\text { Group II } \\
(n=20)\end{array}$ & \\
\hline & No stone, n (\%) & $38(63.3)$ & $9(45.0)$ & $14(70.0)$ & $15(75.0)$ & $\chi^{2}=15.742$ \\
\hline & Mud, n (\%) & $8(13.3)$ & $1(5.0)$ & $2(10.0)$ & $5(25.0)$ & $\mathrm{a} 0.001$ ** \\
\hline & Stone present, $\mathrm{n}(\%)$ & $14(23.3)$ & $10(50.0)$ & $4(20.0)$ & $0(0.0)$ & \\
\hline & No stone, n (\%) & $40(66.7)$ & $9(45.0)$ & $15(75.0)$ & $16(80.0)$ & $\chi^{2}=11.538$ \\
\hline Postoperative & Mud, n (\%) & $5(8.3)$ & $1(5.0)$ & $1(5.0)$ & $3(15.0)$ & $\mathrm{a} 0.010$ * \\
\hline $1^{\text {st }}$ year US result & Stone present, n (\%) & $15(25.0)$ & $10(50.0)$ & $4(20.0)$ & $1(5.0)$ & \\
\hline
\end{tabular}

a: Fisher Freeman Halton Test, ${ }^{\star}: p=0.05,{ }^{\star *}: p=0.001$

deviation, median, frequency, percentage, minimum, maximum) were used while evaluating the study data. Conformity of the quantitative data to a normal distribution was tested both by the Shapiro-Wilk test and by graphical methods. One-way analysis of variance and Bonferroni-corrected binary evaluations were used for comparing more than two groups of quantitative variables with normal distribution. Kruskal-Wallis test and Dunn-Bonferroni test were used for comparing more than two groups of quantitative variables that did not show normal distribution. Pearson chi-square test and Fisher-Freeman-Halton exact test were used to compare qualitative data. Statistical significance was accepted as $p<0.05$.

\section{DISCUSSION}

In this study, the effect of using different doses of UDCA after primary LSG on gallstone formation was investigated. While the development of gallstones decreased with the use of $1000 \mathrm{mg} /$ day UDCA in the $6^{\text {th }}$ month evaluation, it was determined that any dose of UDCA use in the $1^{\text {st }}$ year was protective compared to the control group.

Today, surgery has become the first choice worldwide for those seeking permanent effects in the treatment of obesity. Studies are therefore aimed at increasing the effectiveness of this option and reducing its potential complications (19).

LSG surgery is a completely restrictive method with entero-endocrine system and transit through the normal physiological pathway. Details of CL development mechanism after LSG remain unclear. Low-calorie and low-fat diets cause the development of gallstones by affecting the bile-lipid composition. The bile-lipid content depends on the amount of cholesterol entering the liver. UDCA prevents supersaturation of bile and cholesterol stone formation by inhibiting cholesterol secretion into bile (20).
UDCA as a preventive agent for gallstone formation during weight loss was applied for the first time by Broomfield et al. in 1998 (21). Sugerman et al. and Miller et al. showed that gallstone formation was reduced if patients used UDCA for 6 months after restrictive bariatric surgery $(22,23)$. A meta-analysis showed that UDCA use significantly reduced gallstone formation compared to the placebo group (8.8\% and $27.7 \%$, respectively). As a result, it was reported that UDCA can effectively prevent $\mathrm{CL}$ after bariatric methods (16).

Despite these supportive reports on the use of UDCA, there is still no consensus regarding its routine use in prophylaxis. This may be due to the lack of different criteria defining appropriate indications for the use of UDCA in the light of the risk factors. Gastrointestinal side effects (nausea, vomiting, diarrhea or constipation) may affect patient compliance (24). Although the observed side effects seem to be the biggest obstacle to the continuity of use of the medicine, none of the side effects mentioned above were observed in this study.

Today, the guidelines of the American Association of Clinical Endocrinologists (AACE), the Turkish Obesity Surgery Society (TOSS), and the American Society for Metabolic and Bariatric Surgery (ASMBS) recommend performing routine US for the formation of $C L$ after bariatric surgery, especially in the first six months (25). In our study, we investigated the presence of $\mathrm{mud} / \mathrm{stone}$ in the control US at six and 12 months and its relationship with different doses of UDCA.

Symptomatic gallstones were seen in three $(5 \%)$ of the 60 patients and these were operated on. These three patients were in the control group. Apart from these three patients in the group which did not receive UDCA after LGS, 19 patients were observed to be asymptomatic even though stones or mud were detected on US.

Regarding the key role of cholesterol in hepatic synthesis, dietary intake, and bile acid synthesis, the effect made 
by UDCA in the difference between cholesterol and triglyceride values in the preoperative and postoperative serum and the formation of gallstones was investigated. Differences in cholesterol and triglyceride levels were ignored, as there was no statistical difference in stone formation between the groups.

No correlation was found between gallstone formation after LSG and comorbidities such as DM and hypertension (HT). Since there was no significant difference between the groups, the effects on stone formation in terms of DM were ignored. Although the rate of HT in Group I was found to be higher than that in the other two groups, we think that it may be ignored since there is as yet no study in the literature which shows a relationship between hypertension and gallstones.

Although studies have reported that EWL\% has predictive value for $C L$ development in obese patients, Moon et al., Shiffman et al., and De Oliveira et al. reported no significant difference in mean EWL\% with symptomatic and asymptomatic gallstones after LSG $(3,24,26,27)$. In our study, no significant difference was found between the groups in terms of EWL\% and TWL\%, and the relationship with stone formation was ignored.

This study has some limitations. Although periodic US follow-ups were required for the development of $\mathrm{CL}$ for a longer period, US was only performed at 6 and 12 months in this study. As a result, this may lead to an incorrect assessment of the timing of $\mathrm{CL}$ development and an underestimation of gallstone formation. Since weight loss continues until the $18^{\text {th }}$ month, it would be ideal to perform US control for stone formation until that time. The last of the limitations, and perhaps the most important, is the small sample size.

\section{CONCLUSION}

As a result of our study, it was determined that the use of $500 \mathrm{mg} /$ day UDCA for six months after LSG reduced CL formation in the $1^{\text {st }}$ year, but did not significantly reduce $\mathrm{CL}$ formation in the first six months. It was determined that use of $1000 \mathrm{mg} /$ day UDCA for six months after LSG significantly decreased $C L$ formation in the $6^{\text {th }}$ and $12^{\text {th }}$ months. Therefore, we recommend that patients be given $1000 \mathrm{mg} /$ day UDCA after LSG. However, due to its low number of patients, we believe that this result should be supported by studies with larger sample sizes.

Informed Consent: Written consent was obtained from the participants.

Ethics Committee Approval: This study was approved by the Clinical Research Ethical Committee of the Health Sciences University, Istanbul Fatih Sultan Mehmet Training and Research Hospital (Date: 03.09.2019, No: 12030).
Peer Review: Externally peer-reviewed.

Author Contributions: Conception/Design of Study- M.M.F., A.E., A.T.F.; Data Acquisition- A.Ç., H.Ç., A.B.K., N.E.B.; Data Analysis/Interpretation- A.C.B., K.M.; Drafting ManuscriptM.M.F., A.E., A.T.F., A.C.B.; Critical Revision of Manuscript- A.Ç., H.Ç., A.B.K., N.E.B., K.M.; Approval and Accountability- M.M.F., A.Ç., H.Ç., N.E.B., A.T.F., A.B.K., A.E., A.C.B., K.M.

Conflict of Interest: Authors declared no conflict of interest

Financial Disclosure: Authors declared no financial support.

\section{REFERENCES}

1. Dittrick GW, Thompson JS, Campos D, Bremers D, Sudan D. Gallbladder pathology in morbid obesity. Obes Surg 2005;15(2):238-42. [CrossRef]

2. Fobi MAL, Lee $H$, Igwe $D$, Felahy $B$, James $E$, Stanczyk $M$, et al. Prophylactic cholecystectomy with gastric bypass operation: incidence of gallbladder disease. Obes Surg 2002;12(3):350-3. [CrossRef]

3. Iglézias Brandão de Oliveira C, Adami Chaim E, da Silva BB. Impact of rapid weight reduction on risk of cholelithiasis after bariatric surgery. Obes Surg 2003;13(4):625-8. [CrossRef]

4. Sioka E, Zacharoulis D, Zachari E, Papamargaritis D, Pinaka O, Katsogridaki G, et al. Complicated gallstones after laparoscopic sleeve gastrectomy. J Obes 2014;2014:468203. [CrossRef]

5. Mendez MA, Monteiro CA, Popkin BM. Overweight exceeds underweight among women in most developing countries. Am J Clin Nutr 2005;81(3):714-21. [CrossRef]

6. Stampfer MJ, Maclure KM, Colditz GA, Manson JE, Willett WC. Risk of symptomatic gallstones in women with severe obesity. Am J Clin Nutr 1992;55(3):652-8. [CrossRef]

7. Henao-Morán S, Denova-Gutiérrez E, Morán S, Duque $X$, Gallegos-Carrillo K, Macías N, et al. Recreational physical activity is inversely associated with asymptomatic gallstones in adult Mexican women. Ann Hepatol 2014;13(6):810-8. [CrossRef]

8. Moran S, Milke P, Rodriguez G, Uribe M. Ref: Gallstone formation in obese subjects undergoing a weight reduction diet. Int J Obes Relat Metab Disord 1998;22(3):282-4 [CrossRef]

9. Shiffman ML, Sugerman HJ, Kellum JM, Moore EW. Changes in gallbladder bile composition following gallstone formation and weight reduction. Gastroenterology 1992;103(1):214-21. [CrossRef]

10. Paumgartner G, Sauerbruch T. Gallstones: pathogenesis. Lancet 1991;338(8775):1117-21. [CrossRef]

11. Li VKM, Pulido N, Martinez-Suartez P, Fajnwaks P, Jin HY, Szomstein $S$, et. al. Symptomatic gallstones after sleeve gastrectomy. Surg Endosc 2009;23(11):2488-92. [CrossRef]

12. Yang $H$, Peterson GM, Roth MP, Marks JW. Risk factors for gallstone formation during rapid weight loss. Dig Dis Sci 1992;37(6):912-8. [CrossRef]

13. Zapata R, Severin C, Manriquez M, Valdivieso V. Gallbladder motility and. lithogenesis in obese patients during dietinduced weight loss. Dig Dis Sci 2000;45(2):421-8. [CrossRef] 
14. Amaral JF, Thompson WR. Gallbladder disease in morbidly obese. Am J Surg 1985;149(4):551-7. [CrossRef]

15. Deitel M, Petrov I. Incidence of symptomatic gallstones after bariatric operations. Surg Gynecol Obstet 1987;164(6):54952.

16. Uy MC, Talingdan-Te MC, Espinosa WZ, Daez ML, Ong JP. Ursodeoxycholic acid in the prevention of gallstone formation after bariatric surgery: a meta-analysis. Obes Surg 2008;18(12):1532-38. [CrossRef]

17. Adams LB, Chang C, Pope J, Kim Y, Liu P, Yates A. Randomized, Prospective Comparison of Ursodeoxycholic Acid for the Prevention of Gallstones after Sleeve Gastrectomy. Obes Surg 2016;26(5):990-4. [CrossRef]

18. Şen O, Türkçapar AG, Yerdel MA. Cholelithiasis After Sleeve Gastrectomy and Effectiveness of Ursodeoxycholic Acid Treatment. J Laparoendosc Adv Surg Tech A 2020;30(11):1150-2. [CrossRef]

19. Magouliotis DE, Tasiopoulou VS, Sioka E, Chatedaki C, Zacharoulis D. Impact of bariatric surgery on metabolic and gut microbiota profile: a systematic review and metaanalysis. Obes Surg 2017;27(5):1345-57. [CrossRef]

20. Patel JA, Patel NA, Piper GL, Smith DE, Malhotra G, Colella JJ. Perioperative management of cholelithiasis in patients presenting for laparoscopic Roux-en-Y gastric bypass: have we reached a consensus? Am Surg 2009;75(6):470-6. [CrossRef]

21. Broomfield $\mathrm{PH}$, Chopra R, Sheinbaum RC, Bonorris GG, Silverman A, Schoenfield LJ, et al. Effects of ursodeoxycholic acid and aspirin on the formation of lithogenic bile and gallstones during loss of weight. $\mathrm{N}$ Engl J Med 1988;319(24):1567-72. [CrossRef]
22. Sugerman $H J$, Brewer $W H$, Shiffman $M L$, Brolin RE, Fobi MA, Linner JH, et al. A multicenter, placebo-controlled, randomized, double-blind, prospective trial of prophylactic ursodiol for the prevention of gallstone formation following gastric- bypass-induced rapid weight loss. Am J Surg 1995;169(1):91-6. [CrossRef]

23. Miller K, Hell E, Lang B, Lengauer E. Gallstone formation prophylaxis after gastric restrictive procedures for weight loss: a randomized double-blind placebo-controlled trial. Ann Surg 2003;238(5):697-702. [CrossRef]

24. Manatsathit W, Leelasinjaroen P, Al-Hamid H, Szpunar S, Hawasli A. The incidence of cholelithiasis after sleeve gastrectomy and its association with weight loss: A twocentre retrospective cohort study. Int J Surg 2016;30:13-8. [CrossRef]

25. Mechanick JI, Youdim A, Jones DB, Garvey WT, Hurley $\mathrm{DL}, \mathrm{McMahon} \mathrm{MM}$, et al. American Association of Clinical Endocrinologists, The Obesity Society, and American Society for Metabolic \& Bariatric Surgery medical guidelines for clinical practice for the perioperative nutritional, metabolic, and nonsurgical support of the bariatric surgery patient. Obesity (Silver spring) 2009;17(Suppl 1):S1-70.

26. Moon RC, Teixeira AF, DuCoin C, Varnadore S, Jawad MA. Comparison of cholecystectomy cases after Roux-en-Y gastric bypass, sleeve gastrectomy, and gastric banding. Surg Obes Relat Dis 2014;10(1):64-8. [CrossRef]

27. Shiffman ML, Sugerman HJ, Kellum JM, Brewer WH, Moore EW. Gallstone formation after rapid weight loss: a prospective study in patients undergoing gastric bypass surgery for treatment of morbid obesity. Am J Gastroenterol 1991;86(8):1000-5. 